\title{
Focus on Estimation and Antioxidant Studies of Salacia Species
}

\author{
G. Priya ${ }^{1}$, M. Gopalakrishnan ${ }^{2}$, E. Rajesh ${ }^{3}$ and T. Sekar ${ }^{4 *}$ \\ ${ }^{1} \mathrm{PG}$ and Research Department of Botany, Pachaiyappa's College, Chennai, Tamil Nadu, India \\ ${ }^{2} \mathrm{PG}$ and Research Department of Botany, Pachaiyappa's College, Chennai, Tamil Nadu, India \\ ${ }^{3} \mathrm{PG}$ and Research Department of Botany, Pachaiyappa's College, Chennai, Tamil Nadu, India \\ ${ }^{4} \mathrm{PG}$ and Research Department of Botany, Pachaiyappa's College, Chennai, Tamil Nadu, India \\ "Corresponding authors email: tsekar_bot@yahoo.com
}

Available online at: www.isroset.org

Received: 11/Jan/2019, Accepted: 10/Feb/2019, Online: 28/Feb/2019

\begin{abstract}
Salacia is a valuable medicinal genus found to be composed of various secondary metabolites. Hence, the present study was aimed to estimate three important secondary metabolites such as phenol, flavonoid and tannin. Antioxidant assays such as DPPH assay and ABTS assay and Total Antioxidant Capacity were also studied for this medicinal genus. Seven species of Salacia were considered for this present study. They are Salacia beddomei Gamble, Salacia chinensis L, Salacia fruticosa Heyne ex Lawson, Salacia gambleana Whiting \& Kaul, Salacia macrosperma Wight, Salacia malabarica Gamble, and Salacia oblonga Wall. Various concentrations such as $20 \mu \mathrm{g}, 40 \mu \mathrm{g}, 60 \mu \mathrm{g}, 80 \mu \mathrm{g}$ and $100 \mu \mathrm{g}$ were taken for all studies and the values are entered in terms of Mean $\pm \mathrm{SD}$. In case of DPPH assay and ABTS assay, $\mathrm{IC}_{50}$ values are calculated using ANNOVA and Total Antioxidant Capacity was calculated using a calibration curve.
\end{abstract}

Key Words - Salacia, phenol, flavonoid, tannin, Total Antioxidant Capacity, DPPH, ABTS.

\section{INTRODUCTION}

Salacia is a medicinally important genus belongs to the family Hippocrateaceae, which was formerly known as Celastraceae, Class Magnoliopsida and Order Celastrales [1]. It comprises of about 407 different species and they are widely distributed in South-West India, Peninsular region of India, Sri Lanka, Vietnam, China, Indonesia, Brazil, South Africa, Malaysia, Thailand and Philippines [2,3]. The rich biodiversity of medicinal plants make them a treasure house for obtaining novel compounds either themselves as drugs or pilot molecules for invention of new drugs with different mechanism of action.

Medicinal plants are found to be composed of various phytochemicals also known as secondary metabolites which are used to treat many diseases [4]. The secondary metabolites such as alkaloids, flavonoids, terpenoids, saponins, tannins, glycosides, coumarinsand phenolic compounds are important natural chemical constituents [5,6,7]. These medicinal plants with phytochemicals can be used as a supplement for human diseases by acting as a natural antioxidants [8].

Saurai 2015 [9], Lopez-Alarcon et al 2013 [10] and Martin-Sanchez et al 2014 [11] were studied that polyphenols, such as flavonoids, hydroxycinnamic acids and proanthocyanidins, are considered as a powerful antioxidants and these antioxidants are found to be distributed in various plants especially in forest trees. The flavonols(e.g., quercetin) and hydroxyicinnamicacids (e.g., Caffeic and Ferulic acids) were determined to be more potent antioxidants than ascorbic acid. Hence, this present study was mainly concentrated on estimation of phenol, flavonoid, tannin, total antioxidant capacity and antioxidant assays such as DPPH and ABTS.

The present work was mainly aimed to estimate three important secondary metabolites such as Phenols, Flavonoids, Tannins, Total Antioxidant Capacity etc, also it was focused on the Antioxidant study by carrying out two assays like DPPH and ABTS assays.

\section{MATERIALS AND METHODS Extraction of Plant Materials}

Leaves of seven species of Salacia such as $S$. beddomei, S.chinensis, S.fruticosa, S. gambleana, S.macrosperma, S. malabarica and S.oblongawere collected from Wayanad district of Kerala. They are washed thoroughly, and shade dried. Plant materials were coarsely powdered and soaked in $300 \mathrm{ml}$ of Methanol for $48 \mathrm{hrs}$. The extract was filtered using WhattmannNo.1 filter paper and the filtrate was concentrate under reduced pressure in vacuum at $40^{\circ} \mathrm{C}$ for $25 \mathrm{~min}$ using a rotary evaporator and kept into lyophilisation to remove the traces of solvent.

Estimation Studies 


\section{Total Phenolic Content}

Total phenols were assayed according to Dewanto et al 2002 [12] with some modifications. Various concentrations such as $20 \mu \mathrm{g}, 40 \mu \mathrm{g}, 60 \mu \mathrm{g}, 80 \mu \mathrm{g}$ and $100 \mu \mathrm{g}$ were taken and an aliquot of diluted extract was added to 0.5 $\mathrm{mL}$ of distilled water and $0.125 \mathrm{~mL}$ of Folin-Ciocalteu reagent. The mixture was shaken and allowed to stand for 6 min, before addition of $1.25 \mathrm{~mL}$ of $7 \% \mathrm{Na} 2 \mathrm{CO} 3$. The solution was then adjusted with distilled water to a final volume of $3 \mathrm{~mL}$ and mixed thoroughly. After incubation in the dark, absorbance at $760 \mathrm{~nm}$ was read versus a prepared blank. The total phenol content of plant parts was expressed as milligrams of gallic acid equivalents per gram of dry weight (mg GAE/g DW) from a calibration curve with gallic acid. All samples were analyzed in three replicates.

\section{Total Flavonoid Content}

Total flavonoid content in leaf extracts of $\mathrm{S}$. molesta was determined by aluminum chloride colorimetric method [13]. $0.5 \mathrm{ml}$ of extracts of at a various concentrations such as $20 \mu \mathrm{g}, 40 \mu \mathrm{g}, 60 \mu \mathrm{g}, 80 \mu \mathrm{g}$ and $100 \mu \mathrm{g}$ were taken and the volume was made up to $3 \mathrm{ml}$ with methanol. Then, $0.1 \mathrm{ml} \mathrm{AlCl} 3$ (10\%), $0.1 \mathrm{ml}$ of potassium acetate and $2.8 \mathrm{ml}$ distilled water were added sequentially. The test solution was vigorously shaken. Absorbance was recorded at $415 \mathrm{~nm}$ after 30 minutes of incubation. A standard calibration plot was generated at $415 \mathrm{~nm}$ using known concentrations of quercetin. The concentrations of flavonoid in the test samples were calculated from the calibration plot and expressed as mg quercetin equivalent $(\mathrm{QE}) / \mathrm{g}$ of sample. All samples were analyzed in three replicates.

\section{Total Tannin Content}

The tannins were determined by Folin - Ciocalteu method. Various concentrations such as $20 \mu \mathrm{g}, 40 \mu \mathrm{g}, 60 \mu \mathrm{g}$, $80 \mu \mathrm{g}$ and $100 \mu \mathrm{g}$ were taken. About $0.1 \mathrm{ml}$ of the sample extract was added to a volumetric flask $(10 \mathrm{ml})$ containing $7.5 \mathrm{ml}$ of distilled water and $0.5 \mathrm{ml}$ of Folin-Ciocalteu phenol reagent, $1 \mathrm{ml}$ of $35 \% \mathrm{Na} 2 \mathrm{CO} 3$ solution and dilute to $10 \mathrm{ml}$ with distilled water. The mixture was shaken well and kept at room temperature for $30 \mathrm{~min}$. A set of reference standard solutions of gallic acid were prepared in the same manner as described earlier. Absorbance for test and standard solutions were measured against the blank at 725 $\mathrm{nm}$ with an UV/Visible spectrophotometer. The tannin content was expressed in terms of $\mathrm{mg}$ of GAE /g of extract [14].

\section{Antioxidant Study \\ Total Antioxidant Capacity \\ Phosphomolybdenum assay (PM)}

Total antioxidant activity was estimated by phosphomolybdenum assay [15]. Various concentrations such as $20 \mu \mathrm{g}, 40 \mu \mathrm{g}, 60 \mu \mathrm{g}, 80 \mu \mathrm{g}$ and $100 \mu \mathrm{g}$ were used. Preparation of Molybdate Reagent Solution 1ml each of 0.6
M sulfuric acid, $28 \mathrm{mM}$ sodium phosphate and $4 \mathrm{mM}$ ammonium molybdate were added in $20 \mathrm{ml}$ of distilled water and made up volume to $50 \mathrm{ml}$ by adding distilled water. The Chloroform and ethanolic extracts of Pouzolzia zeylanica and Tribulus terristris were taken in different concentration ranging from 1001 to 5001 were added to each test tube individually containing $3 \mathrm{ml}$ of distilled water and $1 \mathrm{ml}$ of Molybdate reagent solution. These tubes were kept incubated at $95 \mathrm{C}$ for $90 \mathrm{~min}$. After incubation, these tubes were normalized to room temperature for 20-30 min and the absorbance of the reaction mixture was measured at $695 \mathrm{~nm}$. Total Antioxidant activity was expressed in terms of $\mathrm{Mm}$ of Ascorbic acid/g of extract and was calculated using calibration curve.

\section{a. Scavenging effect on 1,1 - diphenyl- 2-picrylhydrazyl radicals (DPPH)}

The free radical scavenging activity of methanolic leaf extract of selected species of Salacia was analysed with stable 1,1 - diphenyl - 2 - picryl hydrazyl radical (DPPH) (Sigma - Aldrich) photo spectrometrically as stated by [16]. Stock solution was prepared with Methanol solution for each plant extract at a concentration of $1 \mathrm{mg} / \mathrm{ml}$. From the stock solution. Various concentrations such as $20 \mu \mathrm{g}, 40 \mu \mathrm{g}, 60 \mu \mathrm{g}$, $80 \mu \mathrm{g}$ and $100 \mu \mathrm{g}$ were taken and mixed with equal volume of Methanolic solution of DPPH $(0.1 \mathrm{mM}) .0 .5 \mathrm{ml}$ of each sample in Methanol solution was mixed with $2.5 \mathrm{ml}$ of 0.5 $\mathrm{mM}$ of Methanolic DPPH solution. The mixture was vortexed vigourously and incubated for 30 minutes in a dark room under room temperature. The absorbance was measured at $517 \mathrm{~nm}$ against a blank using a UV Spectrophotometer (DU 800; Beckman Coulter, Fullerton, CA, USA). Ascorbic acid was used as the positive control. The experiments were conducted in triplicates.

b. Scavenging effect on ABTS radical cation (2,20 azinobis-(3-ethylbenzthiazoline -6-sulphonic acid)

The ABTS cation radical scavenging activity of the extracts was determined according to the modified method of Re et al. (1999) [17]. A stock solution of ABTS was produced by mixing $7 \mathrm{mM}$ aqueous solution of ABTS with $2.45 \mathrm{mM}$ of potassium persulfate in the dark at ambient temperature for $12-16 \mathrm{~h}$ before use. Various concentrations such as $20 \mu \mathrm{g}, 40 \mu \mathrm{g}, 60 \mu \mathrm{g}, 80 \mu \mathrm{g}$ and $100 \mu \mathrm{g}$ were taken. The radical cation solution was further diluted until the initial absorbance value of $0.7 \pm 0.005$ at $734 \mathrm{~nm}$ was reached. For assaying test samples, $0.98 \mathrm{~mL}$ of ABTS solution was mixed with $0.02 \mathrm{~mL}$ of the plant extracts. The decrease in absorbance was recorded at 0 min. and after 6 min. Ascorbic acid was used as the positive control. The experiments were conducted in triplicates.

\section{Statistical analysis}

The data was statistically analyzed by one-way ANNOVA using SPSS 17.0. The difference was considered significant when $\mathrm{p}<0.005$. Triplicate assays were performed for each set of test conditions. All the values were expressed 
as Mean \pm SD (Standard Deviation). IC50 Value is also calculated for all test conditions.

\section{III.RESULTS AND DISCUSSION}

\section{Total Phenolic Content}

Total phenolic content of various species of Salacia such as Salacia beddomei, Salacia chinensis, Salacia fruticosa, Salacia gambleana, Salacia macrosperma, Salacia malabarica and Salacia oblonga was estimated at $84.45 \mathrm{mg} / \mathrm{g}, 85.38 \mathrm{mg} / \mathrm{g}, 64.96 \mathrm{mg} / \mathrm{g}, 68.51 \mathrm{mg} / \mathrm{g}, 81.84$ $\mathrm{mg} / \mathrm{g}, 49.40 \mathrm{mg} / \mathrm{g}$ and $52.19 \mathrm{mg} / \mathrm{g}$ respectively. Gallic acid was taken as positive control which has $47.90 \mathrm{mg} / \mathrm{g}$ of total phenol. Phenols and polyphenols found in plants are two secondary metabolites considered as natural antioxidants. They are usually quantified by using Folin's reagent. They are found to be an effective hydrogen donors widely distributed throgh out the plant kingdom. There is a wide difference between phenolic compounds in the effectiveness as antioxidants [18] (Table $1 \&$ Fig 1).

\section{Total Flavonoid Content}

Total flavonoid content of various species of Salacia was estimated as Salacia beddomei $(54.96 \mathrm{mg} / \mathrm{g})$, Salacia chinensis $(72.37 \mathrm{mg} / \mathrm{g})$, Salacia fruticosa $(61.33$ $\mathrm{mg} / \mathrm{g})$, Salacia gambleana (75.91), Salacia macrosperma (84.96), Salacia malabarica (50.74 mg/g) and Salacia oblonga $(52.73 \mathrm{mg} / \mathrm{g})$ whereas standard positive control quercetin has total flavonoid of $46.94 \mathrm{mg} / \mathrm{g}$ which was lesser than Salacia species. Lee 2007 [19] defined flavonids are the plant pigments which are responsible of the colour of floral parts. Flavonoids are ketonic compounds which can induce anti inflammatory activity and inhibits the oxygen compounds and pro inflammatory activity of an enzyme cyclooxygenase. Moreover, flavonoids possess a potent anti inflammatory activity as they inhibit prostaglandin synthesis (Table 2 \& Fig 2).

\section{Total Tannin Content}

The Tannins form a major group of polyphenols in our diets and are classified into two groups namely hydrolysable tannins and condensed tannins [20]. Total Tannin Content of various species of Salacia was estimated as Salacia beddomei (62.42 mg/g), Salacia chinensis (51.41 $\mathrm{mg} / \mathrm{g})$, Salacia fruticosa $(65.21 \mathrm{mg} / \mathrm{g})$, Salacia gambleana (80.15 mg/g), Salacia macrosperma $(83.97 \mathrm{mg} / \mathrm{g})$, Salacia malabarica $(64.98 \mathrm{mg} / \mathrm{g})$ and Salacia oblonga $(69.17 \mathrm{mg} / \mathrm{g})$ whereas standard positive control Gallic acid contained $52.34 \mathrm{mg} / \mathrm{g}$ of total tannin (Table 3 \& Fig 3).

\section{Antioxidant Study}

Antioxidants are thus useful in protecting cells from such oxidative damage. Synthetic antioxidants, such as butylated hydroxyanisole (BHA) and butylated hydroxytoluene (BHT) are often used as food additives [21]. Natural antioxidants are an interesting alternative in view of their variety of structures and chemical interactions, as well as the numerous biological activities they can perform. Intensive research activities are currently being carried out on plant antioxidants to meet this challenge. Several studies have suggested that polyphenols, such as flavonoids, hydroxycinnamic acids and proanthocyanidins, act as powerful antioxidants.

\section{Total Antioxidant Capacity}

Methanolic leaf extract of Salacia species shows good Total Antioxidant Activity (TAA). Maximum activity was recorded in Salacia macrosperma $(72.36 \mathrm{mg} / \mathrm{g})$ and Salacia beddomei, Salacia fruticosa, Salacia gambleana, Salacia macrosperma, Salacia malabarica, and Salacia oblonga showed activity of $37.75 \mathrm{mg} / \mathrm{g}, 51.19 \mathrm{mg} / \mathrm{g}, 54.06$ $\mathrm{mg} / \mathrm{g}, 65.66 \mathrm{mg} / \mathrm{g}, 68.62 \mathrm{mg} / \mathrm{g}$ respectively. Ascorbic acid was taken as a positive control which showed $30.21 \mathrm{mg} / \mathrm{g}$ of activity. In this study, all seven species of Salacia showed Maximum total antioxidant activity than Ascorbic acid (Positive Control) (Table 4 \& Fig 4).

\section{a. Scavenging effect on 1,1 - diphenyl- 2-picrylhydrazyl radicals (DPPH)}

According to Huang et al 2005 [22], DPPH (2,2diphenyl-1-picryl-hydrazyl-hydrate) free radical method is one of the antioxidant assay which is based on transfer of electrons that produces a violet colour solution on treating with ethanol. DPPH is a free radical and is stable at room temperature, get reduced in the presence of an antioxidant molecule results in colourless ethanol solution. This assay is an easy and rapid method to evaluate antioxidants by spectrophotometric method.

DPPH Radical Scavenging Activity of various concentrations of methanolic extracts of Salacia species such as Salacia beddomei, Salacia chinensis, Salacia fruticosa, Salacia gambleana, Salacia macrosperma, Salacia malabarica and Salacia oblonga was estimated as $105 \mu \mathrm{g} / \mathrm{ml}, 108 \mu \mathrm{g} / \mathrm{ml}, 102 \mu \mathrm{g} / \mathrm{ml}, 100 \mu \mathrm{g} / \mathrm{ml}, 104 \mu \mathrm{g} / \mathrm{ml}$, $110 \mu \mathrm{g} / \mathrm{ml}, 107 \mu \mathrm{g} / \mathrm{ml}$, respectively. Butylated Hydroxy Toluene (BHT) was taken as positive control which showed activity of $195 \mu \mathrm{g} / \mathrm{ml}$ (Table 5).

Many protocols have been carried out for DPPH antioxidant assays which are results in variation of results in different laboratories. Sharma and Bhat (2009) [23] have studied various protocols carried by different workers with incongruity in their results and found out a standard protocol under sensitivity range of spectrophotometry besides sensitivity of DPPH lo light, $\mathrm{pH}$ and solubility of the compound.. 


\section{b. Scavenging effect on ABTS radical cation (2,20 azinobis-(3-ethylbenzthiazoline -6-sulphonic acid)}

ABTS radical scavenging assay employs a specific absorbance of $734 \mathrm{~nm}$ at a wavelength ranging from the visible region and also requires short reaction time. It can be used as an index which reflects the antioxidant activity of the test samples [24]. ABTS assay of various species of Salacia was estimated as Salacia beddomei $(153 \mu \mathrm{g} / \mathrm{ml})$, Salacia chinensis $(167 \mu \mathrm{g} / \mathrm{ml})$, Salacia fruticosa $(146 \mu \mathrm{g} / \mathrm{ml})$, Salacia gambleana $(138 \mu \mathrm{g} / \mathrm{ml})$, Salacia macrosperma $(151 \mu \mathrm{g} / \mathrm{ml})$, Salacia malabarica $(183 \mu \mathrm{g} / \mathrm{ml})$ and Salacia oblonga $(162 \mu \mathrm{g} / \mathrm{ml})$. Ascorbic acid was used as a positive control which showed $201 \mu \mathrm{g} / \mathrm{ml}$ of assay activity (Table 6). This method is used for investigating hydroxybenzoic and hydroxycinnamic acid and it can gets an advantage of the fact that they probably act as radical scavengers owing to their hydrogen and electron donating capacity and their ability to delocalize/stabilize the resulting phenoxyl radical within the structure [25].

\section{CONCLUSION}

The present study investigates the estimation of total phenol, flavonoid, tannin, total antioxidant capacity and antioxidant assays such as DPPH and ABTS assays of seven species of Salacia. The inhibitory property of this extract may be attributed to the presence of phytochemicals such as saponins, phenols and flavonoids. Hence, this valuable genus should be protected in all aspects.

\section{ACKNOWLEDGEMENT}

The authors are thankful to National Medicinal Plants Board, New Delhi for providing financial assistance to carry out this study.

\section{REFERENCES}

[1] Angiosperm Phylogeny Group. An update of the Angiosperm Phylogeny Group classification for the orders and families of flowering plants: APG II. Botanical Journal of the Linnean Society, 141: 399-436. 2003.

[2] C.J. Saldanha. Flora of Karnataka. Oxford and IBH Publishing Co. Pvt. Ltd., New Delhi. 1998.

[3] C. Anshul, S. Singh, A.K. Sharm. Salacia oblonga Wall: A review on its pharmacognostic, phytochemical and pharmacological aspects. Int J Res Pharm Biomed Sci 4: 1215-1218. 2013.

[4] V. Srinivasahan and B. Durairaj. Antioxidant and free radical scavenging effect of Morinda citrifolia fruit extract. Int J Pharma Pharmaceut Sci. 6(4): 55-59. 2014.

[5] H.O. Edeoga, D.E. Okwu, B.O. Mbaebie, Phytochemical constituents of some Nigerian medicinal plants. African Journal of Biotechnology, 4 (7), 685-688. 2005.

[6] P. Tiwari, B. Kumar, M. Kaur, G. Kaur , H. Kaur. Phytochemical screening and extraction, A review: International Journal of Pharmaceutica Sciencie. 1 (1), 98-106. 2011.

[7] Maluventhan Viji, Sangu Murugesan, Phytochemical analysis and antibacterial activity of Medicinal plant Cardiospermum halicacabum Linn. Journal of Phytology, 2 (1), 68-77. 2010.
[8] A.W. Boots, G.R. Haenen, A. Bast, Health effects of quercetin: From antioxidant to nutraceutical. Eur. J. Pharmacol. 585, 325337. 2008.[CrossRef] [PubMed]

[9] P. Saurai, Silymarin as a natural antioxidant: An overview of the current evidence and perspectives. Antioxidants. 4, 204-247. 2015.

[10] C. Lopez-Alarcon, A. Denicola. Evaluating the antioxidant capacity of natural products: A review on chemical and cellularbased assays. Anal.Chim.Acta. 763, 1-10. 2013.

[11] A. Martin-Sanchez, S. Cherif, J. Ben-Abda, X. Barber-Valles, J. Perez-Alvarez, E. Sayas-Barbera. Phytochemicals in date coproducts and their antioxidant activity. Food Chem. 158, 513520. 2014.

[12] X. Dewanto, K. Wu, K. Adom, R..H. Liu. Thermal processing enhances the nutritional value of tomatoes by increasing total antioxidant activity, J. Agric. Food Chem. 50, 3010-3014. 2002.

[13] M.M/ Mervat, E.I. Far, A. Hanan, A. Taie. Antioxidant activities, total anthocyanins, phenolics and flavonoids contents of some sweet potato genotypes under stress of different concentrations of sucrose and sorbitol. Aust J Basic Appl Sci;3: 3609-16. 2009.

[14] Rajeev Singh, Pawan Kumar Verma, Gagandeep Singh. Total phenolic, flavonoids and tannin contents in different extracts of Artemisia absinthium.. J Intercult Ethnopharmacol.1 (2): 101104. 2012.

[15] P. Prieto, M. Pineda and M. Aguilar. Spectrophotometric quantitation of antioxidant capacity through the formation of Phosphomolybdenum Complex: Specific application to the determination of Vitamin E. Anal. Biochem. 269, 337-341. 1999.

[16] M.S. Blois. Antioxidant determinations by the use of a stable free radical. Nature 29: 1199 1200. 1958.

[17] R. Re, N. Pellegrini, A. Proteggente, A. Pannala, M. Yang and C. Rice-Evans. Antioxidant activity applying an improved ABTS radical cation decolorization assay. Free Radicals in Biology and Medicine 26: 1231-1237. 1999.

[18] K. Robards, P.D. Prenzler, G. Tucker, P. Swatsitang , W. Glover. Phenolic compounds and their role in oxidative processes in fruits. Food Chem. 66: 401-436. 1999.

[19] D.Y. Lee. Anti-inflammatory effects of Asparagus cochinchinensis extract in acute and chronic cutaneous inflammation, Journal of ethno pharmacology 114, 234-240. 2007.

[20] J. Dai and R.J Mumper. Plant phenolics: extraction, analysis and their antioxidant and anticancer properties. Molecules. $15: 7313$ 52. 2010.

[21] D. Cekic, A. Cetinkaya, A. Avan, R. Apak,. Correlation of total antioxidant capacity with reactive oxygen species (ROS) consumption measured by oxidative conversion. J. Agric. Food Chem. 61, 5260-5270. 2013.

[22] D.J. Huang, B.X. Ou, R.L. Prior. The chemistry behind antioxidant capacity assays. J Agric Food Chem. 53:1841-1856. 2005.

[23] O.P. Sharma and T.K. Bhat. DPPH antioxidant assay revisited. Food Chemistry, 113: 1202-1205. 2009.

[24] L.C. Wu, H.W. Hsu, Y.C. Chen, C.C. Chiu, Y.I. Lin, J.A. Ho. Antioxidant and antiproliferative activities of red pitaya. Food Chemistry. 95, 319-327. 2006.

[25] A.M. Silva, C.M. Santos, J.A. Cavaleiro, H.R. Tavares, F. Borges, F.A. Silva. NMR studies on the antiradical mechanism of phenolic compounds towards 2.2-diphenyl-1-picrylhydrazyl radical. In: Webb G.A., Belton P.S., Gil A.M., Delgadillo I. editors. Magnetic resonance in food science - A view to the future. 8th ed. London: Royal Society Chemistry, 110-116. 2001. 
Table 1. ESTIMATION OF TOTAL PHENOLIC CONTENT OF VARIOUS SPECIES OF SALACIA

\begin{tabular}{|c|c|c|c|c|c|c|c|c|c|}
\hline S.No & $\begin{array}{c}\text { Concentration } \\
(\mu \mathrm{g})\end{array}$ & $\begin{array}{c}\text { S.beddomei } \\
\text { (Mean } \pm \text { SD) }\end{array}$ & $\begin{array}{c}\text { S.chinensis } \\
\text { (Mean } \pm \text { SD) }\end{array}$ & $\begin{array}{c}\text { S.fruticosa } \\
(\text { Mean } \pm \text { SD) }\end{array}$ & $\begin{array}{l}\text { S.gambleana } \\
(\text { Mean } \pm \text { SD) }\end{array}$ & $\begin{array}{c}\text { S.macrosperma } \\
(\text { Mean } \pm \text { SD })\end{array}$ & $\begin{array}{l}\text { S.malabarica } \\
(\text { Mean } \pm \text { SD })\end{array}$ & $\begin{array}{c}\text { S.oblonga } \\
(\text { Mean } \pm \text { SD) }\end{array}$ & $\begin{array}{c}\text { Gallic Acid } \\
(\text { Mean } \pm \text { SD })\end{array}$ \\
\hline 1. & 20 & $0.391 \pm 0.009$ & $0.313 \pm 0.009$ & $0.380 \pm 0.008$ & $0.319 \pm 0.007$ & $0.376 \pm 0.009$ & $0.324 \pm 0.008$ & $0.372 \pm 0.009$ & $0.125 \pm 0.006$ \\
\hline 2. & 40 & $0.782 \pm 0.006$ & $0.626 \pm 0.006$ & $0.761 \pm 0.010$ & $0.776 \pm 0.007$ & $0.783 \pm 0.007$ & $0.642 \pm 0.009$ & $0.773 \pm 0.009$ & $0.250 \pm 0.010$ \\
\hline 3. & 60 & $1.174 \pm 0.010$ & $0.939 \pm 0.007$ & $1.141 \pm 0.009$ & $0.961 \pm 0.009$ & $0.947 \pm 0.008$ & $1.153 \pm 0.009$ & $1.246 \pm 0.010$ & $0.374 \pm 0.009$ \\
\hline 4. & 80 & $1.565 \pm 0.008$ & $1.253 \pm 0.010$ & $1.522 \pm 0.007$ & $1.541 \pm 0.008$ & $1.387 \pm 0.009$ & $1.543 \pm 0.009$ & $1.462 \pm 0.007$ & $0.499 \pm 0.008$ \\
\hline 5. & 100 & $1.957 \pm 0.011$ & $1.566 \pm 0.007$ & $1.902 \pm 0.008$ & $1.647 \pm 0.009$ & $1.926 \pm 0.007$ & $1.934 \pm 0.009$ & $1.876 \pm 0.007$ & $0.624 \pm 0.006$ \\
\hline
\end{tabular}

Table 2. ESTIMATION OF TOTAL FLAVONOID CONTENT OF VARIOUS SPECIES OF SALACIA

\begin{tabular}{|c|c|c|c|c|c|c|c|c|c|}
\hline S.No & $\begin{array}{c}\text { Concentration } \\
\qquad(\boldsymbol{\mu g})\end{array}$ & $\begin{array}{c}\text { S.beddomei } \\
(\text { Mean } \pm \text { SD) }\end{array}$ & $\begin{array}{c}\text { S.chinensis } \\
\text { (Mean } \pm \text { SD) }\end{array}$ & $\begin{array}{c}\text { S.fruticosa } \\
\text { (Mean } \pm \text { SD) }\end{array}$ & $\begin{array}{l}\text { S.gambleana } \\
(\text { Mean } \pm \text { SD })\end{array}$ & $\begin{array}{c}\text { S.macrosperma } \\
(\text { Mean } \pm \text { SD) }\end{array}$ & $\begin{array}{l}\text { S.malabarica } \\
(\text { Mean } \pm \text { SD })\end{array}$ & $\begin{array}{c}\text { S.oblonga } \\
(\text { Mean } \pm \text { SD) }\end{array}$ & $\begin{array}{c}\text { Gallic Acid } \\
\text { (Mean } \pm \text { SD) }\end{array}$ \\
\hline 1. & 20 & $0.325 \pm 0.007$ & $0.376 \pm 0.008$ & $0.358 \pm 0.010$ & $0.383 \pm 0.008$ & $0.387 \pm 0.009$ & $0.263 \pm 0.007$ & $0.321 \pm 0.006$ & $0.135 \pm 0.009$ \\
\hline 2. & 40 & $0.650 \pm 0.009$ & $0.752 \pm 0.006$ & $0.717 \pm 0.009$ & $0.766 \pm 0.006$ & $0.775 \pm 0.006$ & $0.526 \pm 0.010$ & $0.643 \pm 0.008$ & $0.270 \pm 0.008$ \\
\hline 3. & 60 & $0.976 \pm 0.008$ & $1.128 \pm 0.011$ & $1.076 \pm 0.011$ & $1.149 \pm 0.010$ & $1.162 \pm 0.008$ & $0.790 \pm 0.009$ & $0.964 \pm 0.007$ & $0.406 \pm 0.006$ \\
\hline 4. & 80 & $1.301 \pm 0.010$ & $1.504 \pm 0.010$ & $1.435 \pm 0.008$ & $1.532 \pm 0.007$ & $1.550 \pm 0.006$ & $1.053 \pm 0.007$ & $1.286 \pm 0.010$ & $0.541 \pm 0.007$ \\
\hline 5. & 100 & $1.627 \pm 0.009$ & $1.881 \pm 0.009$ & $1.794 \pm 0.013$ & $1.916 \pm 0.010$ & $1.938 \pm 0.010$ & $1.316 \pm 0.008$ & $1.607 \pm 0.007$ & $0.676 \pm 0.008$ \\
\hline
\end{tabular}

Table 3. ESTIMATION OF TOTAL TANNIN CONTENT OF VARIOUS SPECIES OF SALACIA

\begin{tabular}{|c|c|c|c|c|c|c|c|c|c|}
\hline S.No & $\begin{array}{c}\text { Concentration } \\
\qquad(\mu \mathrm{g})\end{array}$ & $\begin{array}{c}\text { S.beddomei } \\
(\text { Mean } \pm \text { SD) }\end{array}$ & $\begin{array}{c}\text { S.chinensis } \\
(\text { Mean } \pm \text { SD) }\end{array}$ & $\begin{array}{c}\text { S.fruticosa } \\
(\text { Mean } \pm \text { SD) }\end{array}$ & $\begin{array}{l}\text { S.gambleana } \\
(\text { Mean } \pm \text { SD })\end{array}$ & $\begin{array}{c}\text { S.macrosperma } \\
(\text { Mean } \pm \text { SD) }\end{array}$ & $\begin{array}{l}\text { S.malabarica } \\
(\text { Mean } \pm \text { SD) }\end{array}$ & $\begin{array}{c}\text { S.oblonga } \\
(\text { Mean } \pm \text { SD) }\end{array}$ & $\begin{array}{c}\text { Gallic Acid } \\
\text { (Mean } \pm \text { SD) }\end{array}$ \\
\hline 1. & 20 & $0.413 \pm 0.007$ & $0.407 \pm 0.008$ & $0.420 \pm 0.006$ & $0.310 \pm 0.007$ & $0.411 \pm 0.009$ & $0.413 \pm 0.010$ & $0.409 \pm 0.010$ & $0.152 \pm 0.003$ \\
\hline 2. & 40 & $0.826 \pm 0.008$ & $0.814 \pm 0.006$ & $0.841 \pm 0.009$ & $0.622 \pm 0.009$ & $0.822 \pm 0.009$ & $0.826 \pm 0.009$ & $0.818 \pm 0.009$ & $0.304 \pm 0.005$ \\
\hline 3. & 60 & $1.240 \pm 0.006$ & $1.220 \pm 0.009$ & $1.261 \pm 0.008$ & $0.932 \pm 0.010$ & $1.233 \pm 0.008$ & $1.239 \pm 0.011$ & $1.227 \pm 0.007$ & $0.456 \pm 0.002$ \\
\hline 4. & 80 & $1.653 \pm 0.009$ & $1.627 \pm 0.007$ & $1.682 \pm 0.010$ & $1.243 \pm 0.008$ & $1.644 \pm 0.006$ & $1.652 \pm 0.008$ & $1.636 \pm 0.006$ & $0.609 \pm 0.003$ \\
\hline 5. & 100 & $2.066 \pm 0.010$ & $2.034 \pm 0.010$ & $2.102 \pm 0.008$ & $1.554 \pm 0.006$ & $2.055 \pm 0.010$ & $2.065 \pm 0.012$ & $2.045 \pm 0.009$ & $0.761 \pm 0.004$ \\
\hline
\end{tabular}

Table 4. TOTAL ANTIOXIDANT CAPACITY (TAC) OF VARIOUS SPECIES OF SALACIA

\begin{tabular}{|c|c|c|c|c|c|c|c|c|c|}
\hline S.No & $\begin{array}{c}\text { Concentration } \\
(\mu \mathrm{g})\end{array}$ & $\begin{array}{c}\text { S.beddomei } \\
\text { (Mean } \pm \text { SD) }\end{array}$ & $\begin{array}{c}\text { S.chinensis } \\
\text { (Mean } \pm \text { SD) }\end{array}$ & $\begin{array}{c}\text { S.fruticosa } \\
\text { (Mean } \pm \text { SD) }\end{array}$ & $\begin{array}{l}\text { S.gambleana } \\
(\text { Mean } \pm \text { SD })\end{array}$ & $\begin{array}{c}\text { S.macrosperma } \\
(\text { Mean } \pm \text { SD })\end{array}$ & $\begin{array}{l}\text { S.malabarica } \\
(\text { Mean } \pm \text { SD })\end{array}$ & $\begin{array}{c}\text { S.oblonga } \\
\text { (Mean } \pm \text { SD) }\end{array}$ & $\begin{array}{l}\text { Ascorbic Acid } \\
(\text { Mean } \pm \text { SD })\end{array}$ \\
\hline 1. & 20 & $0.184 \pm 0.006$ & $0.717 \pm 0.009$ & $0.268 \pm 0.010$ & $0.276 \pm 0.006$ & $0.217 \pm 0.008$ & $0.328 \pm 0.009$ & $0.297 \pm 0.009$ & $0.026 \pm 0.007$ \\
\hline 2. & 40 & $0.328 \pm 0.009$ & $0.757 \pm 0.007$ & $0.357 \pm 0.008$ & $0.378 \pm 0.010$ & $0.348 \pm 0.010$ & $0.467 \pm 0.010$ & $0.524 \pm 0.005$ & $0.068 \pm 0.009$ \\
\hline 3. & 60 & $0.672 \pm 0.008$ & $0.976 \pm 0.006$ & $0.475 \pm 0.007$ & $0.527 \pm 0.009$ & $0.525 \pm 0.006$ & $0.674 \pm 0.007$ & $0.776 \pm 0.007$ & $0.136 \pm 0.008$ \\
\hline 4. & 80 & $0.924 \pm 0.007$ & $1.028 \pm 0.010$ & $0.616 \pm 0.007$ & $0.875 \pm 0.006$ & $0.656 \pm 0.007$ & $0.725 \pm 0.007$ & $0.815 \pm 0.007$ & $0.326 \pm 0.007$ \\
\hline 5. & 100 & $1.078 \pm 0.010$ & $1.145 \pm 0.006$ & $0.937 \pm 0.008$ & $1.026 \pm 0.007$ & $0.925 \pm 0.006$ & $1.096 \pm 0.006$ & $1.117 \pm 0.009$ & $0.578 \pm 0.010$ \\
\hline \multicolumn{2}{|c|}{ Total Antioxidant Capacity (TAC) } & $37.75 \mathrm{mg} / \mathrm{g}$ & $36.71 \mathrm{mg} / \mathrm{g}$ & $51.19 \mathrm{mg} / \mathrm{g}$ & $54.06 \mathrm{mg} / \mathrm{g}$ & $72.36 \mathrm{mg} / \mathrm{g}$ & $65.66 \mathrm{mg} / \mathrm{g}$ & $68.62 \mathrm{mg} / \mathrm{g}$ & $30.21 \mathrm{mg} / \mathrm{g}$ \\
\hline
\end{tabular}


Table 5. DPPH ASSAY OF VARIOUS SPECIES OF SALACIA

\begin{tabular}{|c|c|c|c|c|c|c|c|c|c|}
\hline S.No & $\begin{array}{c}\text { Concentration } \\
(\mu \mathrm{g})\end{array}$ & $\begin{array}{c}\text { S.beddomei } \\
\text { (Mean } \pm \text { SD) }\end{array}$ & $\begin{array}{c}\text { S.chinensis } \\
\text { (Mean } \pm \text { SD) }\end{array}$ & $\begin{array}{c}\text { S.fruticosa } \\
\text { (Mean } \pm \text { SD) }\end{array}$ & $\begin{array}{l}\text { S.gambleana } \\
(\text { Mean } \pm \text { SD) }\end{array}$ & $\begin{array}{c}\text { S.macrosperma } \\
(\text { Mean } \pm \text { SD })\end{array}$ & $\begin{array}{r}\text { S.malabarica } \\
(\text { Mean } \pm \text { SD) }\end{array}$ & $\begin{array}{c}\text { S.oblonga } \\
(\text { Mean } \pm \text { SD) }\end{array}$ & $\begin{array}{c}\text { BHT } \\
(\text { Mean } \pm \mathrm{SD})\end{array}$ \\
\hline 1. & 20 & $41.25 \pm 0.064$ & $46.12 \pm 0.073$ & $51.23 \pm 0.031$ & $43.21 \pm 0.029$ & $41.19 \pm 0.065$ & $39.82 \pm 0.072$ & $43.23 \pm 0.046$ & $23.96 \pm 0.083$ \\
\hline 2. & 40 & $41.53 \pm 0.034$ & $49.74 \pm 0.037$ & $54.01 \pm 0.056$ & $45.63 \pm 0.038$ & $43.25 \pm 0.043$ & $42.71 \pm 0.051$ & $44.41 \pm 0.040$ & $28.49 \pm 0.071$ \\
\hline 3. & 60 & $44.67 \pm 0.037$ & $54.06 \pm 0.058$ & $56.23 \pm 0.158$ & $50.01 \pm 0.031$ & $52.38 \pm 0.032$ & $45.08 \pm 0.049$ & $46.81 \pm 0.037$ & $33.61 \pm 0.089$ \\
\hline 4. & 80 & $52.54 \pm 0.037$ & $56.49 \pm 0.160$ & $57.31 \pm 0.063$ & $52.29 \pm 0.042$ & $55.63 \pm 0.057$ & $49.18 \pm 0.032$ & $49.02 \pm 0.033$ & $35.02 \pm 0.068$ \\
\hline 5. & 100 & $56.70 \pm 0.099$ & $57.55 \pm 0.061$ & $60.12 \pm 0.052$ & $59.89 \pm 0.069$ & $57.01 \pm 0.049$ & $55.13 \pm 0.031$ & $53.72 \pm 0.041$ & $38.80 \pm 0.056$ \\
\hline \multicolumn{2}{|r|}{$\mathrm{IC}_{50}$ Value } & $105 \mu \mathrm{g} / \mathrm{ml}$ & $108 \mu \mathrm{g} / \mathrm{ml}$ & $102 \mu \mathrm{g} / \mathrm{ml}$ & $100 \mu \mathrm{g} / \mathrm{ml}$ & $104 \mu \mathrm{g} / \mathrm{ml}$ & $110 \mu \mathrm{g} / \mathrm{ml}$ & $107 \mu \mathrm{g} / \mathrm{ml}$ & $195 \mu \mathrm{g} / \mathrm{ml}$ \\
\hline \multicolumn{2}{|r|}{ P - Value } & 0.000 & 0.000 & 0.000 & 0.000 & 0.000 & 0.000 & 0.000 & 0.000 \\
\hline
\end{tabular}

Table 6. ABTS ASSAY OF VARIOUS SPECIES OF SALACIA

\begin{tabular}{|c|c|c|c|c|c|c|c|c|c|}
\hline S.No & $\begin{array}{c}\text { Concentration } \\
(\mu \mathrm{g})\end{array}$ & $\begin{array}{c}\text { S.beddomei } \\
(\text { Mean } \pm \text { SD) }\end{array}$ & $\begin{array}{c}\text { S.chinensis } \\
(\text { Mean } \pm \text { SD) }\end{array}$ & $\begin{array}{c}\text { S.fruticosa } \\
\text { (Mean } \pm \text { SD) }\end{array}$ & $\begin{array}{l}\text { S.gambleana } \\
(\text { Mean } \pm \text { SD })\end{array}$ & $\begin{array}{c}\text { S.macrosperma } \\
(\text { Mean } \pm \text { SD) }\end{array}$ & $\begin{array}{l}\text { S.malabarica } \\
(\text { Mean } \pm \text { SD) }\end{array}$ & $\begin{array}{c}\text { S.oblonga } \\
(\text { Mean } \pm \text { SD) }\end{array}$ & $\begin{array}{c}\text { Ascorbic Acid } \\
(\text { Mean } \pm \text { SD })\end{array}$ \\
\hline 1. & 20 & $29.32 \pm 0.081$ & $28.46 \pm 0.076$ & $32.86 \pm 0.064$ & $31.09 \pm 0.072$ & $29.86 \pm 0.078$ & $21.08 \pm 0.082$ & $32.18 \pm 0.078$ & $18.16 \pm 0.098$ \\
\hline 2. & 40 & $29.63 \pm 0.063$ & $29.01 \pm 0.081$ & $39.23 \pm 0.048$ & $39.83 \pm 0.059$ & $30.12 \pm 0.043$ & $30.23 \pm 0.064$ & $36.06 \pm 0.063$ & $21.32 \pm 0.086$ \\
\hline 3. & 60 & $32.98 \pm 0.066$ & $42.08 \pm 0.061$ & $41.32 \pm 0.028$ & $41.32 \pm 0.061$ & $39.68 \pm 0.063$ & $38.07 \pm 0.078$ & $40.61 \pm 0.053$ & $29.48 \pm 0.061$ \\
\hline 4. & 80 & $38.01 \pm 0.072$ & $46.14 \pm 0.086$ & $46.03 \pm 0.032$ & $50.89 \pm 0.093$ & $42.86 \pm 0.042$ & $44.18 \pm 0.056$ & $43.20 \pm 0.038$ & $33.04 \pm 0.082$ \\
\hline 5. & 100 & $43.30 \pm 0.053$ & $51.10 \pm 0.053$ & $50.13 \pm 0.041$ & $52.61 \pm 0.081$ & $51.03 \pm 0.061$ & $49.53 \pm 0.036$ & $46.13 \pm 0.043$ & $45.61 \pm 0.059$ \\
\hline \multicolumn{2}{|c|}{ IC $_{50}$ Value } & $153 \mu \mathrm{g} / \mathrm{ml}$ & $167 \mu \mathrm{g} / \mathrm{ml}$ & $146 \mu \mathrm{g} / \mathrm{ml}$ & $138 \mu \mathrm{g} / \mathrm{ml}$ & $151 \mu \mathrm{g} / \mathrm{ml}$ & $183 \mu \mathrm{g} / \mathrm{ml}$ & $162 \mu \mathrm{g} / \mathrm{ml}$ & $201 \mu \mathrm{g} / \mathrm{ml}$ \\
\hline \multicolumn{2}{|r|}{ P - Value } & 0.000 & 0.000 & 0.000 & 0.000 & 0.000 & 0.000 & 0.000 & 0.000 \\
\hline
\end{tabular}

Fig 1. TOTAL PHENOLIC CONTENT OF SALACIA SPECIES
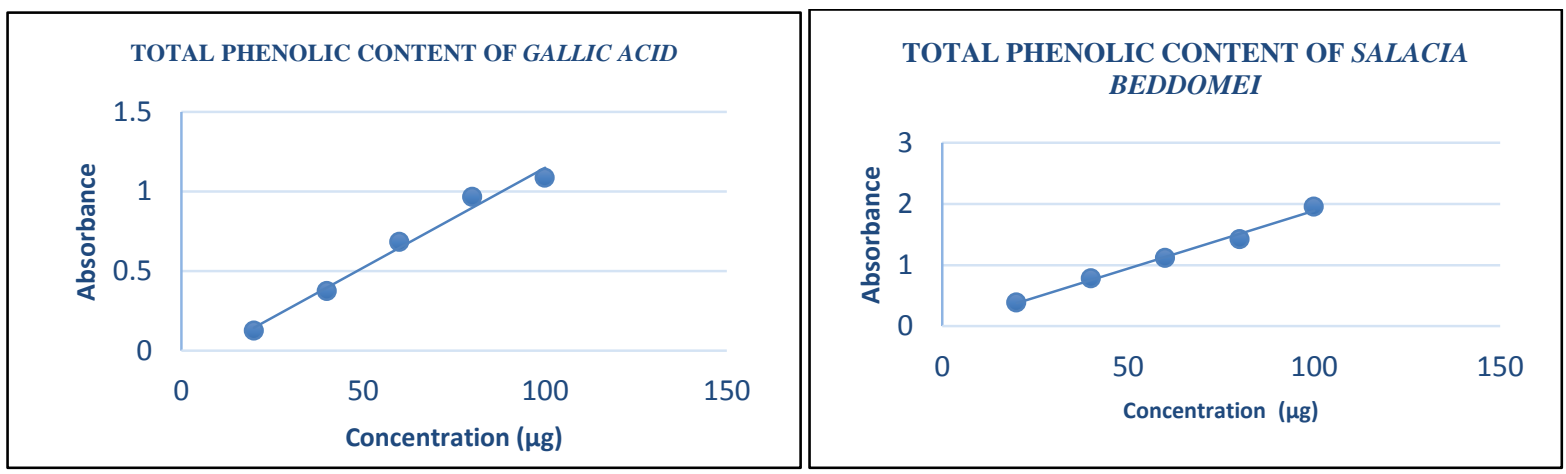

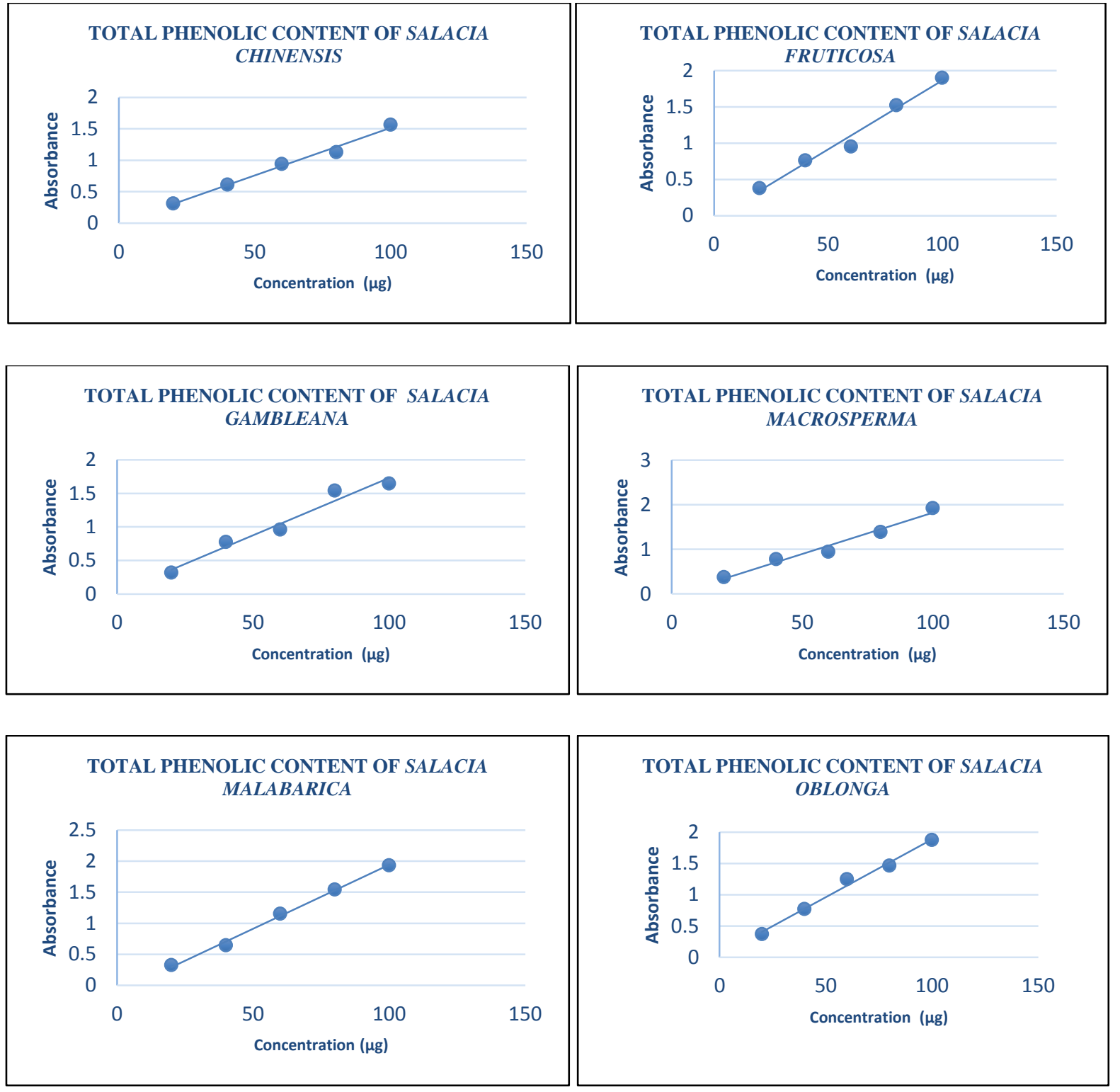

TOTAL PHENOLIC CONTENT OF SALACIA OBLONGA

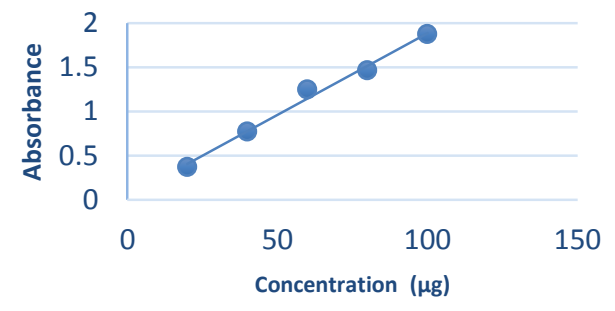

Fig 2. TOTAL FLAVONOID CONTENT OF SALACIA SPECIES
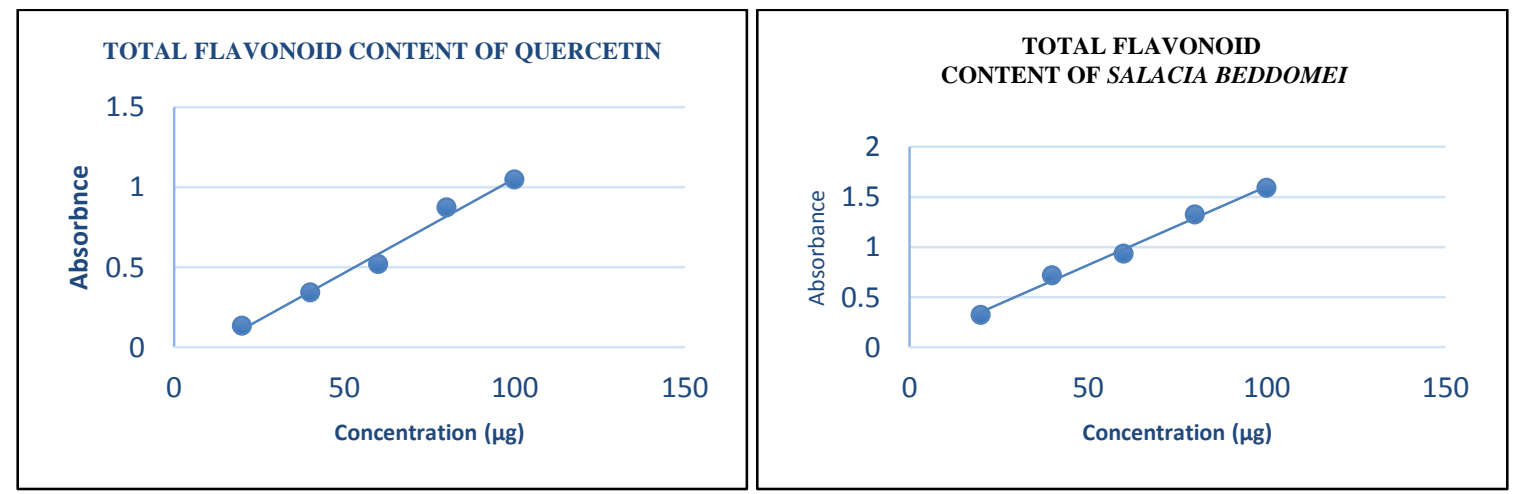

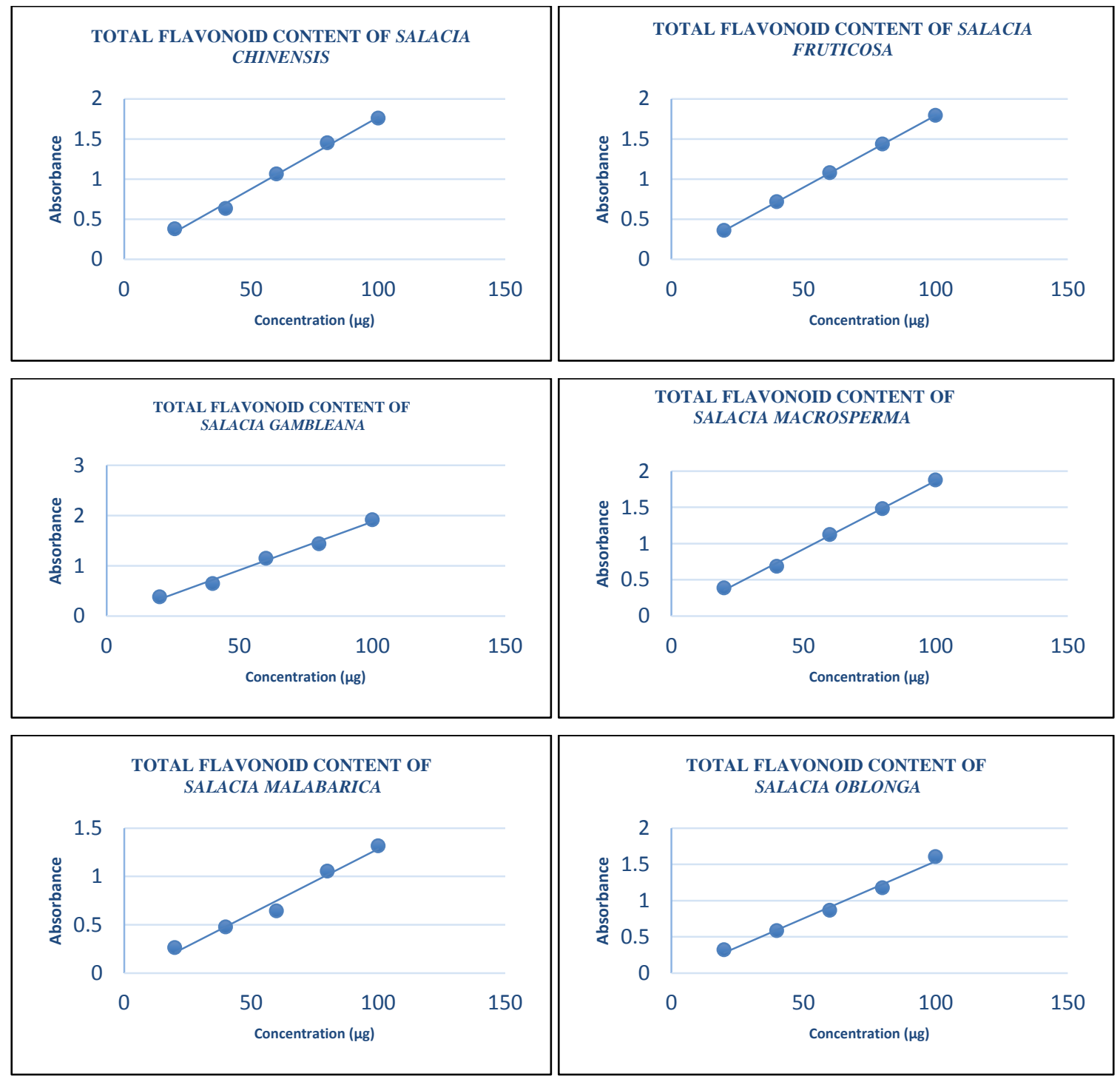

Fig 3. TOTAL TANNIN CONTENT OF SALACIA SPECIES
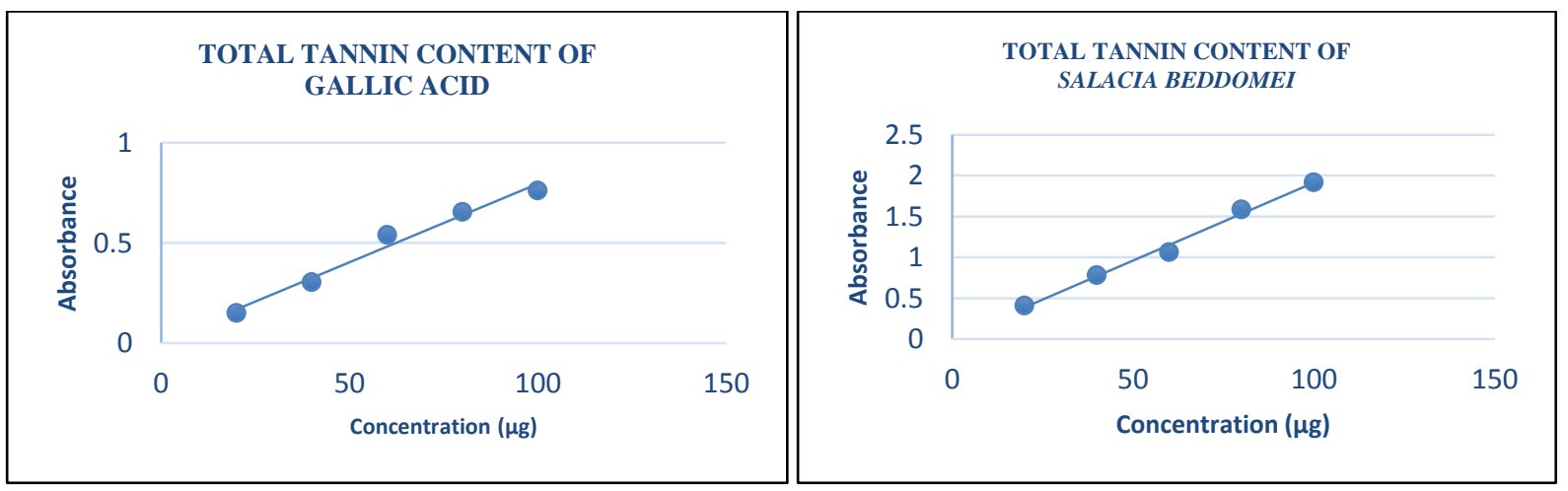

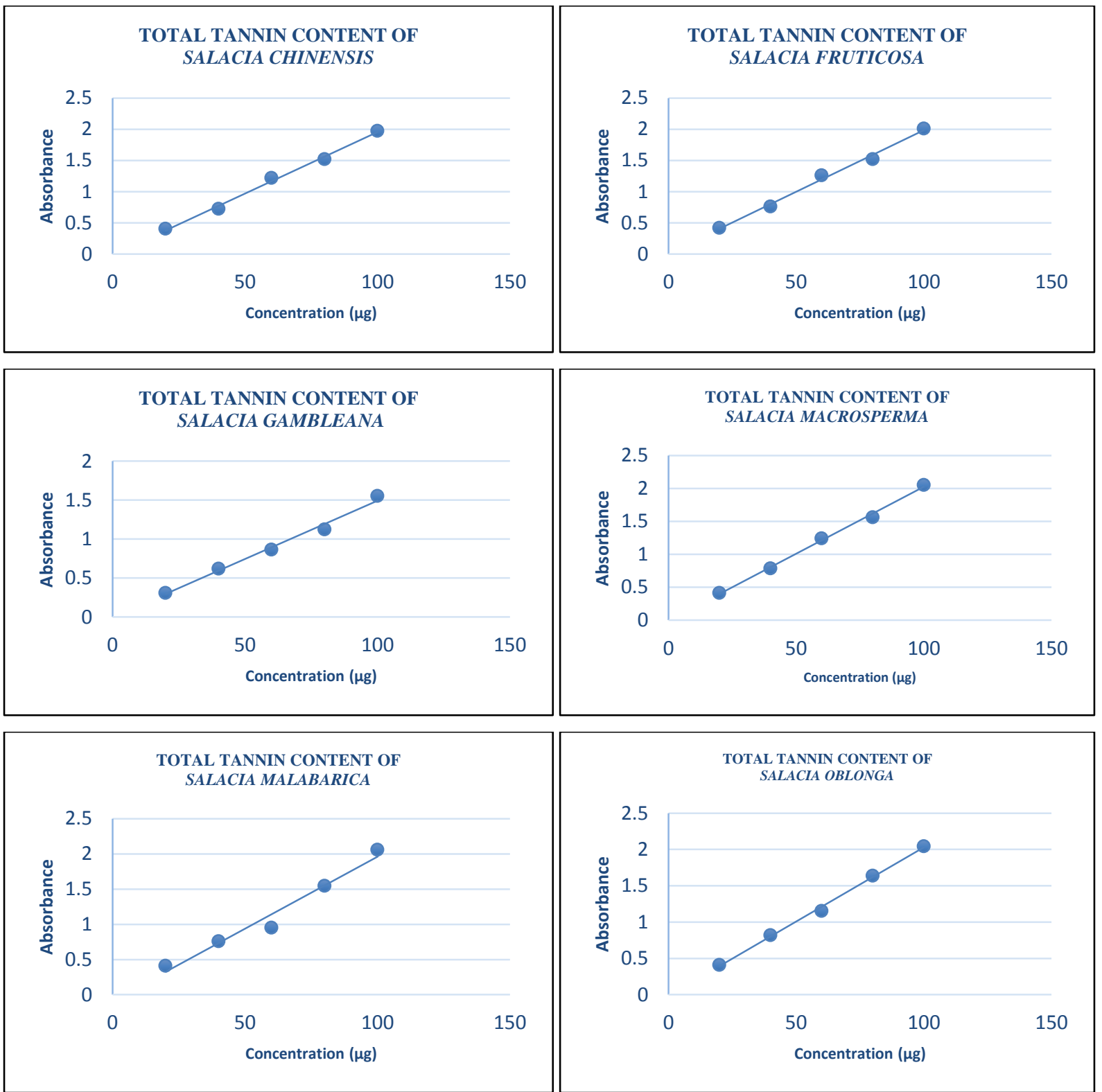

Fig 4. TOTAL ANTIOXIDANT CAPACITY OF SALACIA SPECIES
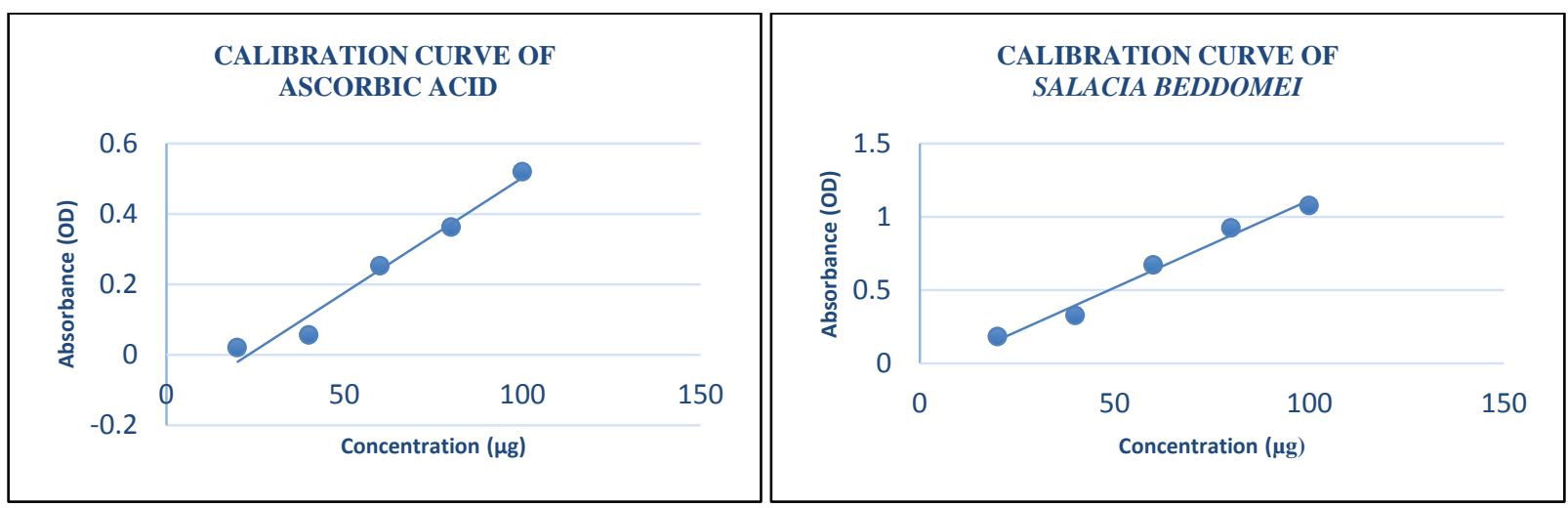

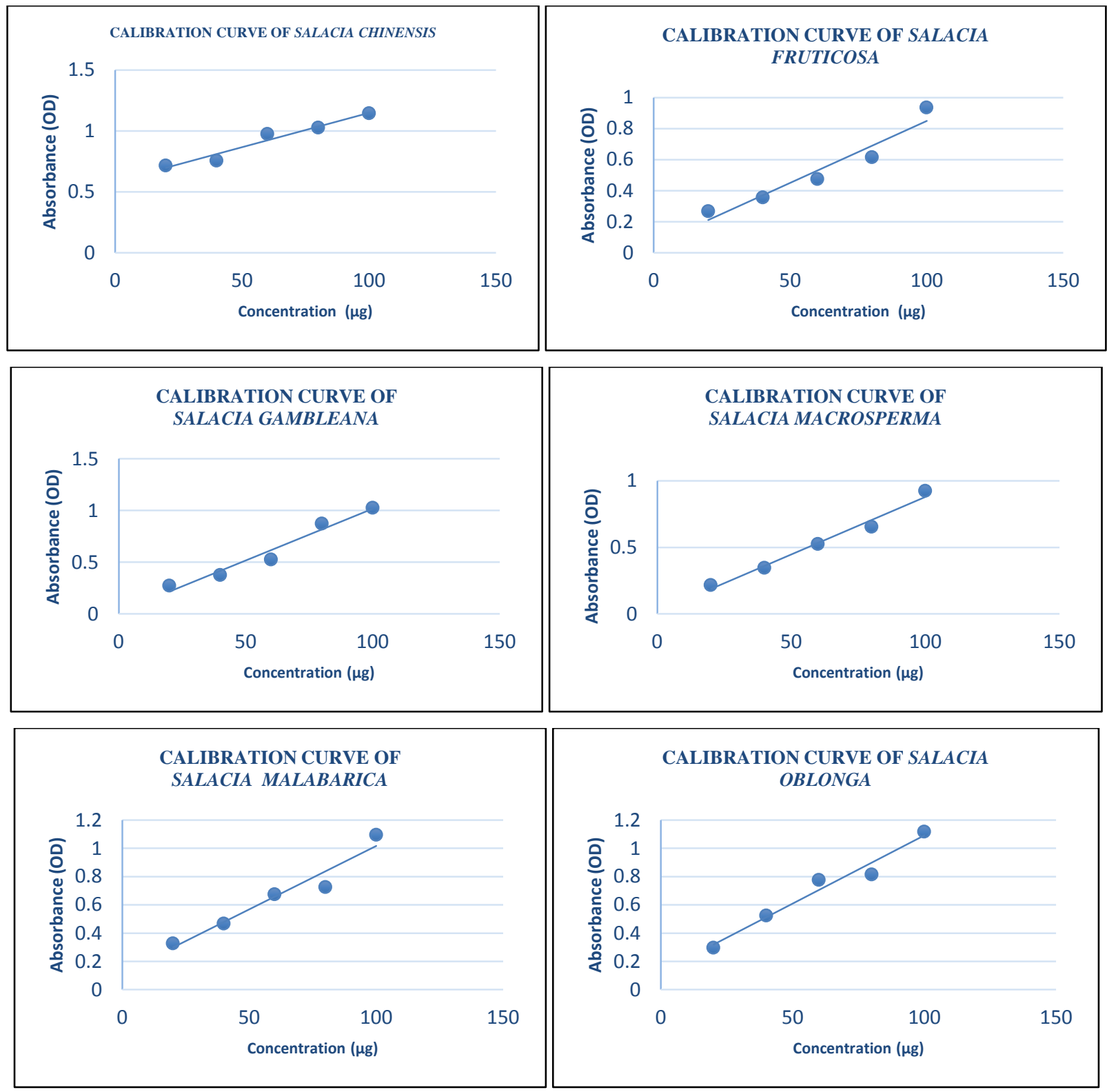